\title{
Gastric Plasmablastic Lymphoma, A Very Rare Tumor
}

\author{
Diego Armando Barraza Ortiz ${ }^{1 *}$, Johanna Cevallos Espinel ${ }^{2}$, Mauro Eduardo Ramírez Solís ${ }^{1}$, Angélica Iztaccíhuatl \\ Hernández Guerrero ${ }^{1}$ \\ ${ }^{1}$ Gastrointestinal endoscopy service, Instituto Nacional de Cancerología, Mexico \\ ${ }^{2}$ Pathological anatomy service, Instituto Nacional de Cancerología, Mexico
}

Submission: November 11, 2020; Published: December 10, 2020

*Corresponding author: Diego Armando Barraza Ortiz, address: calle 4 oriente, number 91, Suburb isidro fabela, Postal Code 14030 Tlalpan, mexico city, Mexico

\section{Abstract}

Plasmablastic lymphoma is a rare variety of diffuse large B-cell lymphoma, regularly aggressive, usually localized in the oral cavity in patients with human immunodeficiency virus infection. Uncommon extraoral locations include the gastrointestinal tract. The endoscopic view of the tumor in the stomach is presented as well as its response to chemotherapy.

Keywords: Gastric plasmablastic lymphoma; Gastric tumor; Endoscopy

\section{Introduction}

Plasmablastic lymphoma is a rare and aggressive non-Hodgkin lymphoma subtype that mainly affects patients infected with human immunodeficiency virus (HIV), in whom it tends to present in the oral cavity where the typical presentation is considered, in immunocompetent patients they have been described cases of advanced age and location outside the oral cavity [1]. This type of lymphoma rarely affects the digestive tract, with very few cases reported in the literature involving the stomach, small intestine, and colon [2]. Its pathogenesis is still not fully understood, the Epstein-Barr virus (EBV) has been shown to be present in most cases and a small percentage of cases is associated with MYC gene rearrangement [3]. Due to its rarity, the treatment of this type of lymphoma is challenging with very poor response rates, and very poor survival [4]. There are very few published cases in the literature about the endoscopic appearance of this type of lymphoma, there is increasing evidence of its appearance in immunocompetent elderly people such as our case.

\section{Case Report}

A 72-year-old male patient, with no history of chronic degenerative diseases, negative HIV, began his current condition 6 months previously with burning epigastric pain, early satiety, 10 $\mathrm{kg}$ weight loss, and hematemesis. A panendoscopy is performed which reports a tumor on a greater curvature where biopsies are taken, the response to chemotherapy is also observed (Figure 1). Pathology report with plasmablastic lymphoma without association with Epstein Barr virus (Figure 2). Hematology was sent to the patient who started treatment with cyclophosphamide, dexamethasone, and thalidomide with clinical improvement.

\section{Discussion}

HIV infection is very important when it comes to this type of lymphoma, since it has been seen that in HIV positive patients the location in the oral cavity is the most frequent, in HIV negative patients the extranodal location in the digestive tract, mainly the stomach, is the site of most frequent appearance [5]. The endoscopic image of gastric plasmablastic lymphoma in our case, we see that it differs clearly from the typical image of a gastric adenocarcinoma, so emphasis should be placed on adequate endoscopic semiology to increase the level of diagnostic suspicion of this rare type of gastric lymphoma. Regarding the endoscopic response after chemotherapy, we see that it responded partially with the administered scheme, with a significant decrease in size. 


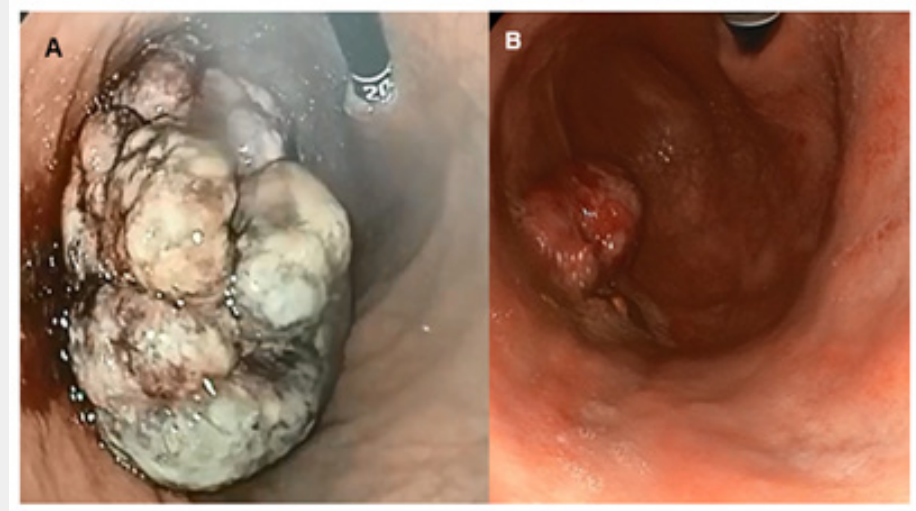

Figure 1: Endoscopic view of gastric plasmablastic lymphoma. A. A gastric tumor is observed on a greater curvature in retrovision, exophytic, vegetating, multilobed, approximately $9 \mathrm{~cm}$ in its long axis, whitish in color with violaceous areas, of a stone consistency. B. Same tumor as image A, after chemotherapy 3 months later, we see a significant decrease in size.

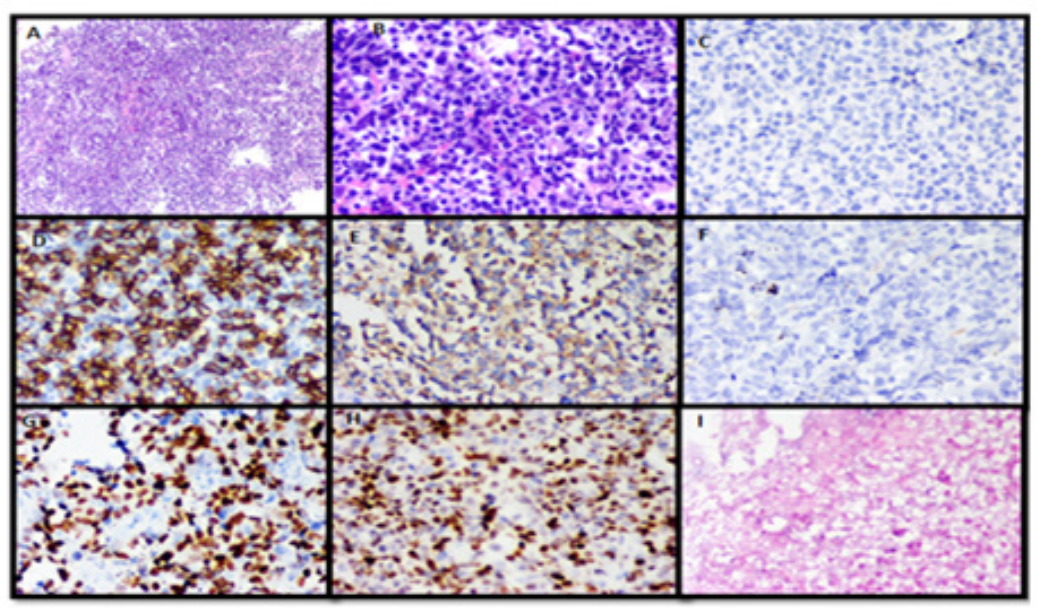

Figure 2: Histomicrographs. A, B. H / E staining, 4 x / 0.10 and $40 \mathrm{X} / 0.65$, gastric mucosa is observed replaced by malignant neoplasm that is arranged in a diffuse pattern, the cells are of intermediate size, some have a plasmacytoid appearance and others have basophilic nucleoli visible. C. IHC-CD20, 40x/0.65. negative in neoplastic cells. D, E, G IHC-138, KAPPA, MUM-1, 40x/0.65: Positive in neoplastic cells. F. IHC-LAMBDA, 40X, negative in neoplastic cells. H. IHC-KI67, 40x/0.65: Positive 80\%. I. EBER-ISH, 40X/0.65: negative. Abbreviations: H/E: hematoxylin / Eosin, IHC: immunohistochemical. MUM-1: protein of the lymphocytic and melanocytic lineage. KI67: cell proliferation factor. EBER-ISH: Non-coding ribonucleic acid associated with Epstein-Barr virus by in situ hybridization.

\section{References}

1. Marques I, Ana Lagos, Beatriz Costa Neves (2013) Gastric plasmablastic lymphoma in HIV-negative patient. Rev Esp Enferm Dig (Madrid) 105(3): 166-167.

2. Luria L, Johnny Nguyen, Jun Zhou, Michael Jaglal, Lubomir Sokol, et al. (2014) Manifestations of gastrointestinal plasmablastic lymphoma: A case series with literature review. World J Gastroenterol 20(33): 11894-11903.

3. Lopez A, Pau Abrisqueta (2018) Plasmablastic lymphoma: current perspectives. Blood and Lymphatic Cancer: Targets and Therapy 8: 6370.

4. Castillo JJ, Winer ES, Stachurski D, Perez K, Jabbour M, Milani C et al (2010) Clinical andpathological differences between human immunodeficiency virus-positive andhuman immunodeficiency virusnegative patients with plasmablastic lymp-homa. Leuk Lymphoma 51: 2047-2053.

5. Castillo JJ, Reagan JL (2011) Plasmablastic lymphoma: a systematic review. Scientific World Journal 11: 687-696. 


\section{Your next submission with JuniperPublishers will reach you the below assets}

- Quality Editorial service

- Swift Peer Review

- Reprints availability

- E-prints Service

- Manuscript Podcast for convenient understanding

- Global attainment for your research

- Manuscript accessibility in different formats ( Pdf, E-pub, Full Text, audio)

- Unceasing customer service

Track the below URL for one-step submission https://juniperpublishers.com/online-submission.php 